\title{
The Monetary Policy of the ECB: Caring for the Weakest Links
}

\author{
Marcus Drometer, Thomas Siemsen and Sebastian Watzka*
}

\section{INTRODUCTION}

It is well known that the common policy rate set by the ECB is not optimal for most national economies as structural differences, distinct national business cycles and asymmetric shocks remain considerable even almost two decades after the introduction of the Euro (Berger and de Haan (2002)). The divergent national interests have become apparent in the ongoing euro crisis where politicians, journalists and economists from different countries fundamentally disagree over the true state of the world and even more over the appropriate monetary policy measures. For example, the disagreement over the ECB's current low interest rate policy is mainly caused by its distributional consequences that differ across countries. ${ }^{1}$ However, little is known whether conflicts of interest between the euro area member countries played an important role in the ECB's decision before the onset of the euro crisis. At that time monetary policy and its implications were confined to experts and did not attain much attention in the media. The ECB itself emphasized that decisions followed a census among experts without reference to national interests, best illustrated by its first president as follows: "The members of the Governing Council consider the interests of the Euro as a whole; they do not represent their respective countries." (Duisenberg, 2002). We challenge the validity of this statement and investigate to which extent national interests played a role in the ECB's decision process even before the onset of the euro crisis. As a novel feature, we test whether countries that fare

* Marcus Drometer (corresponding author), ifo Institute for Economic Research, Poschingerstraße 5, 81679 München, Germany, drometer@ifo.de. We thank Gerhard Illing, Timo Wollmershäuser, Francisco Ruge-Murcia, two anonymous referees, participants at the 2014 Meeting of the European Public Choice Society in Cambridge, the Macro Research Seminar at the Ludwig-Maximilians-Universität München, seminars at the ifo Institute and at IWH Halle for many helpful comments and suggestions. An earlier version of this paper circulated under the title "The Monetary Policy of the ECB: A Robin Hood Approach?".

${ }^{1}$ See, e.g., The Economist (2016), 30.04.2016. 
economically worse than the euro area average obtain more weight in the decision process than warranted by their economic size.

As no information on the ECB Governing Council's decision-making process is made public, ${ }^{2}$ we approximate the optimal interest rates of the individual euro area members by counterfactual rates, i.e. the interest rates national central banks would set if they still had the discretion to do so. As there are numerous ways of deriving such counterfactual interest rate paths, we follow Hayo and Méon (2013) and build our analysis $\mathrm{n}$ a broad set approaches by employing the average of estimates based on Hayo (2007), Eleftheriou, Gerdesmeier, and Roffia (2006) and Taylor (1993). We then employ various potential decision models to aggregate the counterfactual national interest rates and test which of the resulting interest paths fits best to the actual monetary policy in the euro area. We are the first to test bargaining models where the governors of countries that fare economically worse than the euro area average obtain a higher weight in the decision process. For that purpose, we introduce two decision models which classify certain countries as weak which then obtain a higher weight in the central bank's policy rule: In the first specification, we define a country as weak if its output gap is more negative (less positive) than the average euro area output gap. In the second specification, we define a country as weak if its nationally preferred interest rate is below the (GDP weighted) average euro area interest rate. Finally, we implement the Diebold and Mariano (2002) test statistic that allows to test whether two competing forecasts differ in their explanatory power. This allows us to make us an informed, quantitative judgment when assessing the goodness of fit of the different interest rate paths generated in our analysis.

Our results suggest that these models explain actual ECB policy even better than GDP based bargaining models that have been highlighted in the previous literature (see, e.g., Hayo and Méon (2013)). Thus, the ECB seems to have emphasized the needs of countries that fare economically worse disproportionately high than the euro area average even before the advent of the financial crisis. This finding is remarkable since the ECB itself often denied that its monetary policy is especially focused on countries that are in an economic crisis. ${ }^{3}$ An explanation for our findings might be that the effort of a governor in the bargaining process depends on the level of pressure from his home country which in turn depends on its current economic situation. ECB governors might be more active when their home country is facing a crisis as contended by Bindseil (2001) or when they are influenced by being under the spotlight of their home countries' media as argued by Heinemann and Huefner (2004). Our results have far-reaching policy implications: if the ECB's monetary policy was biased towards

${ }^{2}$ Even the minutes of the Governing Council's meetings published since 2015 are not sufficiently informative.

${ }^{3} \mathrm{Cf}$. interview with Jens Weidmann, Wirtschaftswoche, 21.12.2013. 
economically weak countries even before the onset of the euro crisis when the ECB's policy did not gather a lot of political attention, such a bias is likely a systematic feature - and arguably a construction failure of the euro area which will not disappear as soon as the turmoil of the euro crisis ends.

Our paper is structured as follows: Section II provides an overview of the related literature. Section III describes the derivation of counterfactual policy rates for the euro area member countries. Various potential ECB decision models are introduced in section IV. Section V presents the results of our analysis and discusses possible explanations for our findings. The robustness of our results is tested in section VI. Finally, section VII concludes.

\section{LITERATURE REVIEW}

Numerous studies have analyzed whether regional factors affect the decisionmaking process of monetary policy committees. ${ }^{4}$ Most of this literature refers to the U.S. Federal Reserve Bank's (Fed) Federal Open Market Committee (FOMC) and asks whether regional factors play a role in explaining the observed voting patterns. Gildea (1992) finds that the votes of regional Fed presidents in the FOMC can partly be predicted by the level of unemployment rates in the regions they represent. Meade and Sheets (2005) confirm the view that committee members do not exclusively focus on the performance of the national economy, but take into account the economic situation of their region. They show that this behavioral pattern is also relevant for Board members, who are supposed to represent only federal interests. More recent studies confirm that regional considerations matter for the Fed's monetary policy deliberations: Tillmann (2011) shows that non-voting FOMC members systematically overpredict inflation relative to the consensus forecast. In addition to that, Jung and Latsos (2015) find that the regional bias is limited to only few Fed Presidents.

In the case of the ECB the opinions (and decisions) of monetary policy committees may differ substantially they represent different countries with different business cycles that face different economic problems (Berger and de Haan (2002)). A number of studies investigate whether regional factors influence the ECB's decisions, but find only limited evidence for this hypothesis. ${ }^{5}$ Heinemann and Huefner (2004) develop a generalized Taylor-type reaction function that allows for the influence of regional divergence, but find supportive evidence only under some specifications. In a similar analysis, Ullrich (2006) includes

\footnotetext{
${ }^{4} \mathrm{~A}$ further strand of the literature studies the impact of the bibliographical background on the performance of monetary policy committees. For example, Farvaque, Stanek, and Vigeant (2014) show that committee members coming from academia, central banks and the financial sector positively affect the performance of monetary policy committees.

${ }^{5}$ Similarly, Gunzinger and Sturm (2016) study to which extent political constraints affect the size of stimulus packages that were enacted in the wake of the crisis.
} 
country-specific economic variables in addition to euro area aggregates, but does not find convincing evidence that these factors influence the decisions of the ECB Governing Council.

Several studies estimate Taylor rules for the euro area and calculate the implicit policy weights of the individual member countries. Sturm and Wollmershäuser (2008) investigate the adequacy of the single monetary policy by calculating country-specific monetary stress for the euro area countries. They find that business cycles within the euro area only converge if more than proportional weight is attached to small member countries. Similarly, Hayo and Méon (2013) estimate counterfactual interest rates for the euro area countries via Taylor rules. These nationally preferred rates are aggregated according to different decision models and compared to the actual rates set by the ECB. The authors conclude that a GDP based bargaining model best explains the ECB's actual monetary policy. Riboni and Ruge-Murcia (2010) analyze the interest rate setting of five central banks (including the ECB) to determine the decision rule employed. In their analysis, a consensus model, where a supermajority is required to change the interest rate, performs best. Such a rule creates a gridlock interval thus producing a high level of persistence of the interest rate.

Our study extends the above literature by allowing the influence of a country in the ECB's decision process to depend on its current (relative) economic performance. ${ }^{6}$ Therefore, we introduce two decision models which classify certain countries as weak which then obtain a higher weight in the central bank's policy rule and implement the Diebold and Mariano (2002) test statistic that allows us to make an informed, quantitative judgment when assessing the goodness of fit of the different interest rate paths generated in our analysis.

\section{APPROXIMATING NATIONAL INTEREST RATES}

As no detailed information on how the Governing Council reaches its decisions is made public, we need to infer its policy rule from the ECB's monetary policy and observable macroeconomic characteristics of the euro area member countries. ${ }^{7}$ The ECB's policy stance can be approximated by the short-term interest rate EONIA which we use to operationalize monetary policy actions as it is perceived to be the main policy instrument of central banks (Borio, 1997). ${ }^{8}$ The interest rates that the individual euro area countries prefer, i.e. the interest rates that the national governors would like to set if they could still conduct

\footnotetext{
${ }^{6}$ When analyzing speeches delivered by members of the Governing Council, Bennani and Neuenkirch (2017) find that after the financial crisis divergent national economic conditions are the main driver of a home bias. ${ }^{7}$ The ECB publishes minutes of the Governing Council's meetings since 2015. However, these are not detailed enough to infer the voting decision of individual governors systematically.

${ }^{8}$ The ECB does not fully control EONIA, but significant deviations were very limited during the period considered in our analysis.
} 
independent monetary policy, are more demanding to obtain. We use counterfactual interest rate based on Taylor rule approximations and observable macroeconomic variables following most of the literature. ${ }^{9}$ As there are many ways to specify Taylors rules and to calibrate the corresponding coefficients, we use a broad set of different approaches and provide several robustness checks based on different pre-existing approximations. Based on Taylor (1993) a simple policy rule defines the behavior of a central bank as a function of the deviation of inflation from its target and the output gap:

$$
i_{t}=r^{*}+\pi^{*}+\beta_{1}\left(\pi_{t}-\pi^{*}\right)+\beta_{2} y_{t}
$$

with $i_{t}$ denoting the target nominal interest rate, $r^{*}$ the long-run real interest rate, $\pi_{t}$ the inflation rate, $\pi^{*}$ the target inflation rate and $y_{t}$ the output gap.

For our analysis, we build on previous work that simulated counterfactual national interest paths using historical data from pre-Euro age. ${ }^{10}$ Eleftheriou, Gerdesmeier, and Roffia (2006) estimate Taylor-type interest rate rules are with monthly national data from the period from 1993 to 1998 for eleven EMU countries. They find that the country specific rules are distinct from each other and differ substantially from the standard Taylor rule, but in most cases the estimated rules reproduce the actual ECB policy quite closely. Similarly, Hayo (2007) calibrates Taylor rules using monthly data on the euro area members' monetary policy during the last 20 years before the formation of EMU. ${ }^{11}$ These long-run rules allow to simulate country-specific interest rates based on the expected one-year ahead inflation rate and the current output gap. As evident when comparing the estimated country-specific Taylor rule coefficients in both studies, each calibration depends considerably on the precise specification. A frequently employed safe alternative is to simply use the original rule suggested by John Taylor (Taylor, 1993), which is completely agnostic of specific calibrations, but completely misses the peculiarities of the individual countries. To make our analysis as independent as possible of any particular choice of method, we follow Hayo and Méon (2013) who use the simple average of the three specifications by Eleftheriou, Gerdesmeier, and Roffia (2006), Hayo (2007) and Taylor (1993). In section VI we show that our results are robust to using each of the three above time series of counterfactual interest rates separately.

The period considered in our analysis ranges from the introduction of the Euro in January 1999 to December 2006. This period offers substantial variation both in the general economic climate and ECB policy. If the ECB was ever able to conduct monetary policy independent of national political interests, it was during

\footnotetext{
${ }^{9}$ See, e.g., Bénassy-Quéré and Turkish (2009) and Hayo and Méon (2013).

${ }^{10}$ We thank Bernd Hayo and Pierre-Guillaume Méon for generously sharing their data with us.

${ }^{11}$ The target inflation rate $\pi^{*}$ is considered constant at $2 \%$ and real interest rates $r^{*}$ are assumed to be constant.
} 
that period. Since the onset of the financial crisis national interests have become more apparent, but at the same time the crisis hinders the extension of our analysis. With the introduction of non-standard measures, the ECB's policy has become multi-dimensional and cannot be captured a single measure such as EONIA anymore. ${ }^{12}$

\section{DECISION MODELS}

The Maastricht Treaty regulates the ECB's primary objectives (the maintenance of price stability (art. 105), its political independence (art. 107)) and the institutional framework within which the ECB takes its decisions. ${ }^{13}$ The ECB's monetary decisions are taken by the Governing Council which is comprised of the (currently) 19 governors of the national central banks and six Executive Board members appointed by the European Council. According to its statutes, decisions are taken by simple majority rule in the Governing Council. ${ }^{14}$ In the past, however, the ECB emphasized that decisions follow a census among experts without reference to national interests. It remains an open question how the ECB's statutes are interpreted de facto as no detailed information on the Governing Council's decisions are publicly available. Therefore, we map the nationally preferred interest rates into monetary policy paths according to different decision models and test which decision model best explains actual monetary policy.

\section{IV.1. Weak country decision models}

Several decision models have been proposed by the previous literature. Hayo and Méon (2013) argue that a simple Nash-bargaining model best explains the behavior of the Governing Council. It is defined as the GDP weighted average of the individual countries' preferred interest rates, i.e.,

$$
i_{t}^{E C B}=\sum_{c=1}^{C} G D P_{-} \text {Share }_{c t} * i_{c t}^{*},
$$

where $C$ indicates the number of euro area member countries and $i_{c t}^{*}$ the optimal interest $i$ for country $c$ in year $t$. The model assumes that all members of the Governing Council follow national interests and that their bargaining weight depends on their countries' GDP.

We take the above decision model as a starting point and offer an extension where the weight of a country in the decision-making process depends on its

\footnotetext{
${ }^{12}$ Moreover, we have chosen the period 1999 to 2006 to make our study comparable to Hayo and Méon (2013).

${ }^{13} \mathrm{~A}$ large normative literature discusses the optimal design of monetary policy committees in currency unions. For a detailed survey see Bénassy-Quéré and Turkish (2009).

${ }^{14}$ See Article 10.1 of the "Protocol of the statute of the European System of Central Banks and of the European Central Bank".
} 
current economic conditions. Thus, these models do not simply reflect the economic size of the euro area member countries but also the heterogeneity of the national economic environments. The idea behind this refinement is that the effort of the governors in the bargaining process is not constant, but depends on their standing in their home country. In particular, governors of countries experiencing a recession are likely to experience more political pressure and thus exert more effort to influence the common monetary policy. Consequently, countries that face adverse economic conditions become more relevant in the decision process.

Our first specification of the weak country model is the output gap model. It measures an unfortunate economic situation in terms of a country's output gap relative to the euro area output gap. If a country's output gap is smaller or more negative than the euro area output gap, it is defined as economically weak. ${ }^{15}$ For the calculation of the associated ECB policy, $i_{t}^{O G}$, the countries defined as weak obtain the double GDP weight in the decision process, i.e.,

$$
i_{t}^{O G}=\sum_{c=1}^{c=\tilde{c}} 2 * A d j_{-} G D P_{-} \text {Share }_{c t} * i_{c t}^{*}+\sum_{c>\tilde{c}}^{C} \text { Adj_GDP_Share } \text { St }_{c} * i_{c t}^{*}
$$

where $\widetilde{c}$ indicates the last country with an output gap that is smaller or more negative than the euro area output gap when ordering all countries according to their output gap.Adj_GDP_Share ${ }_{c t}$ represents the normalized GDP share of country $i$ in year $t$. Of course, the assumption of the double weight is only a very rough approximation which we relax by conducting a sensitivity analysis (see section V).

Our second specification of the weak country model is the preferred rate model. It defines a country as weak if the nationally preferred interest rate is lower than the (GDP-weighted) euro area average. ${ }^{16}$ For the calculation of the associated ECB policy, $i_{t}^{P R}$, the countries defined as weak obtain the double GDP weight in the decision process, i.e.,

$$
i_{t}^{P R}=\sum_{c=1}^{c=\hat{c}} 2 * A d j_{-} G D P_{-} \text {Share }_{c t} * i_{c t}^{*}+\sum_{c>\hat{c}}^{C} \text { Adj_GDP_Share }_{c t} * i_{c t}^{*}
$$

where $\widehat{c}$ indicates the last country with a preferred national interest rate that is smaller than the average euro area interest rate when ordering all countries according to their preferred national interest rate starting with the lowest one.

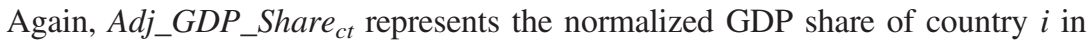
year $t$. Finally, we relax the assumption of a double weight for weak countries in section $\mathrm{V}$.

\footnotetext{
${ }^{15}$ The countries defined as weak economies under the output gap criterion are listed in the appendix.

${ }^{16}$ The countries defined as weak economies under the preferred rate criterion are listed in the appendix.
} 
The members of the Executive Board, however, do not directly represent their home country and might vote in their own country's interest or take a euro area perspective. Following Hayo and Méon (2013), we develop two scenarios, one with a board that takes on a common euro area perspective ("federalist board") as well as one with executive board members that represent their home countries' interests ("nationalist board"). Most of the literature on monetary unions assumes that monetary decisions of common central banks are based on union-wide aggregates (see e.g. Alesina and Grilli (1992) and Gros and Hefeker (2002)). Thus, we model the federal perspective as a GDP weighted average of the preferred interest rates of all euro area member countries. ${ }^{17}$ As evident from our results, the differences between the two concepts do not affect our results qualitatively.

In principle, weak countries in the euro area could be defined in other ways different from the two ideas incorporated in the output and the preferred model. Therefore, we have tried several further scenarios. We tested a recession model (higher weight if a country's growth rate is below zero), a low growth model (higher weight if a country's growth rate is below one) and a below average growth model (higher weight if a country's growth rate is below its long-term average). ${ }^{18}$ As all these models perform worse than our two main scenarios (for details see appendix), we decided to present the output and the preferred model only.

\section{IV.2. Further political economy decision models}

Political economy decision models have been discussed extensively in Riboni and Ruge- Murcia (2010). The most straightforward political economy model to start with is majority voting as prescribed by ECB's official rules. Due to the single dimension of monetary policy and the single-peakedness of the country-specific policy preference, the median voter theorem applies. ${ }^{19}$ Hence, the outcome of the process can be easily determined as the median of the distribution of the nationally optimal interest rates. Alternatively, the members of the Governing Council might bargain over monetary policy. We apply a GDPweighted bargaining model and a simple bargaining model where all members have the same bargaining weight independent of the size of their country. Given the prominent role of the ECB president, one might expect that the Governing Council's decisions are strongly influenced by his or her country's interests. To account for this possibility, we implement an agenda-setting rule where the

\footnotetext{
${ }^{17}$ Similarly, Aksoy, de Grauwe, and Dewachter (2002) approximate the scenario where the GoverningCouncil takes on a euro-wide perspective as a weighted average of the desired interest rates of the individual countries.

${ }^{18} \mathrm{We}$ would like to thank an anonymous reviewer for that suggestion.

${ }^{19} \mathrm{As}$ in the following we assume that individuals vote as if they are pivotal like in Riboni and Ruge-Murcia (2010).
} 
chairman dominates the decision process: The chairman sets the agenda, proposing one alternative to the last period's interest rate. Then the committee decides on whether to implement this new proposal or to stay with the previous rate by simple majority vote. This agenda-setting power allows the chairman to influence the decision process and often creates a gridlock, meaning that a certain interest rate can persist several periods. ${ }^{20}$ Finally, we consider a consensus rule that requires a supermajority for any changes in monetary policy. Riboni and Ruge-Murcia (2010) argue that such a rule best describes the decision-making of monetary committees, mainly because it often results in a gridlock interval where no changes occur, thus producing a high level of persistence in the interest rate. In contrast, with a majority voting rule, the identity of the crucial median committee member, and hence the interest rate selected, are likely to change from one meeting to the next. Accordingly, in a first stage the committee decides by simple majority whether to decrease or increase the interest rate. In a second stage, a two-thirds majority, is required to increase/decrease the interest rate incrementally. Otherwise, the status quo prevails. ${ }^{21}$ Any further changes are also taken in incremental steps and require a supermajority. As soon as no such majority is willing to change the interest rate any more, the process ends. ${ }^{22}$ In contrast, with a majority voting rule, the identity of the crucial median committee member, and hence the interest rate selected, are likely to change from one meeting to the next. As before, we also need to make an assumption on how members of the Executive Board behave. Again, we distinguish between a "federalist board" and a "nationalist board". As shown in the following the resulting differences between the two concepts are rather small and do not affect our results qualitatively.

\section{RESULTS}

The outcome of the different decision models is illustrated graphically in Figure 1 (a) to (g) (versions with federalist board shown). All models roughly predict the movements of the actual interest rate. However, the output gap model clearly stands out as being very close to the EONIA path. The preferred rate,

\footnotetext{
${ }^{20}$ For example, if $i_{\text {median }}^{*}<i_{\text {chairman }}^{*}<i_{\text {status quo }}^{*}$ the chairman can simply propose his bliss point which is supported by the median given the alternative of staying with the status quo. For a detailed discussion see Riboni and Ruge-Murcia (2010).

${ }^{21}$ As with the chairman model the status quo at the beginning of the game is not clearly defined. In our analysis we simply use the average rate. Comparisons with alternatives as the GPD weighted average show that the decision loses importance after less than a handful periods.

${ }^{22}$ For a detailed description see Riboni and Ruge-Murcia (2010). Note that this consensus rule needs to be distinguished from a "consensus among experts" which involves the members of the Governing Council jointly maximizing an objective function.
} 


\section{MARCUS DROMETER/THOMAS SIEMSEN/SEBASTIAN WATZKA}

Figure 1

Goodness-of-fit comparison for different decision models. (a) Output gap model, (b) Preferred rate model, (c) Simple bargaining model, (d) GDP bargaining model, (e) Majority voting model, (f) Consensus model, (g) Chairman dominance model, (h) Franco-German dominance model

(a) Output gap model

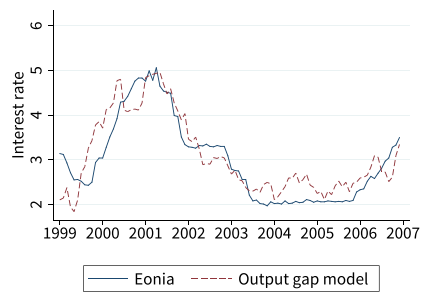

(c) Simple bargaining model

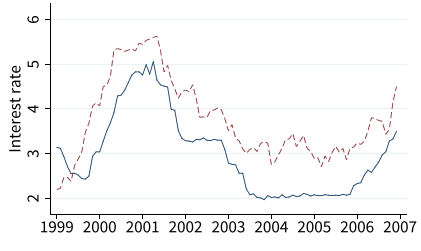

_- Eonia ----- Simple bargaining model

(e) Majority voting model

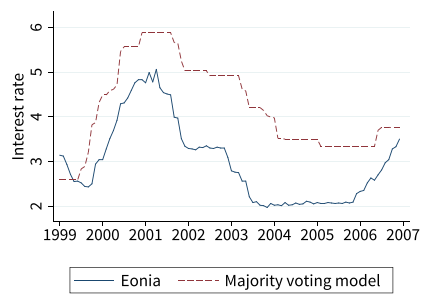

(g) Chairman dominance model

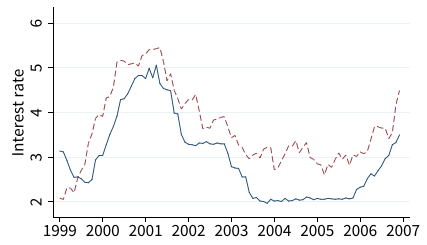

- Eonia ----- Chairman model (b) Preferred rate model

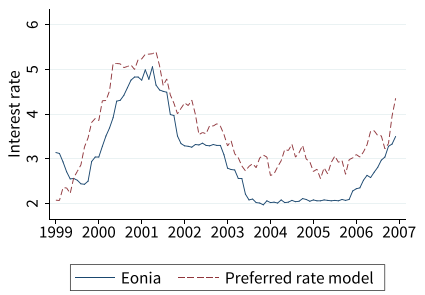

(d) GDP bargaining model

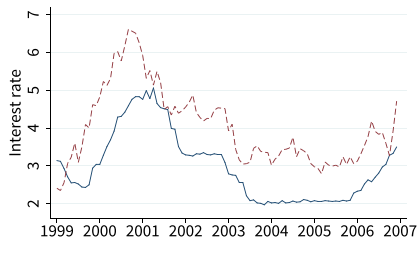

_- Eonia ----. GDP bargaining model

(f) Consensus model

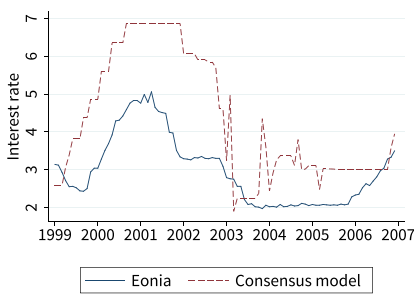

(h) Franco-German dominance model

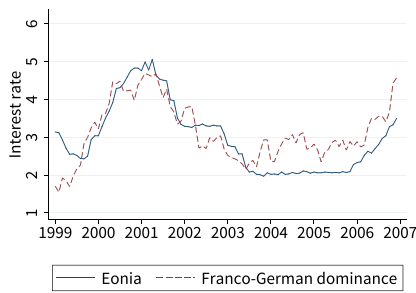

Note: Figures plot the time-series of EONIA (blue solid line) and the outcome of the different decision models (red dashed line) from 01/1999 to 12/2006. Details see section 4 .

Note: Figures plot the time-series of EONIA (blue solid line) and the outcome of the different decision models (red dashed line) from 01/1999 to 12/2006. Details see section 4. 
Table 1

Summary Statistics

\begin{tabular}{llccccc}
\hline Decision model & \multicolumn{1}{c}{ Preferences } & No. Obs. & Mean & Std. Dev. & Min & Max \\
\hline Eonia & & 96 & 2.98 & 0.91 & 1.97 & 5.06 \\
Output gap & Federalist board & 96 & 3.08 & 0.86 & 1.84 & 4.96 \\
Output gap & Nationalist board & 96 & 2.74 & 0.87 & 1.55 & 4.62 \\
Preferred rate & Federalist board & 96 & 3.58 & 0.88 & 2.07 & 5.40 \\
Preferred rate & Nationalist board & 96 & 3.44 & 0.85 & 1.90 & 5.20 \\
Simple bargaining & Federalist board & 96 & 4.09 & 1.00 & 2.45 & 6.14 \\
Simple bargaining & Nationalist board & 96 & 4.24 & 1.01 & 2.56 & 6.32 \\
GDP Bargaining & Federalist board & 96 & 3.77 & 0.90 & 2.20 & 5.63 \\
GDP Bargaining & Nationalist board & 96 & 3.73 & 0.87 & 2.13 & 5.55 \\
Majority voting & Federalist board & 96 & 3.78 & 0.91 & 2.20 & 5.63 \\
Majority voting & Nationalist board & 96 & 4.06 & 1.02 & 2.35 & 6.56 \\
Consensus & Federalist board & 96 & 3.83 & 0.89 & 2.31 & 5.47 \\
Consensus & Nationalist board & 96 & 4.22 & 0.97 & 2.56 & 5.87 \\
Chairman dominance & Federalist board & 96 & 3.98 & 1.41 & 1.81 & 5.85 \\
Chairman dominance & Nationalist board & 96 & 4.29 & 1.66 & 0.91 & 6.79 \\
Franco-German dominance & & 96 & 3.14 & 0.783 & 1.55 & 4.69 \\
\hline
\end{tabular}

Note: The sample ranges from January 1999 to December 2006. The output gap model defines an unfortunate economic situation if a country's output gap is smaller or more negative than the euro area output gap. The preferred rate model refers to a country as weak if the nationally pre- ferred interest rate is lower than the (GDP-weighted) euro area average. For the details of the further decision models see section IV. In the "federalist board" scenarios, the executive board is assumed to take a common euro area perspective. In the the "nationalist board" scenario, the executive board members represent their home countries' interests.

bargaining and majority voting models generate rather spiky interest rate paths. Only the consensus and the chairman dominance model allow to generate longer periods of stable interest rates, however, the latter appears to be quite sensitive to small changes in the underlying parameters. Table 1 summarizes the predicted means and standard deviations of the different model outcomes. In line with existing findings, the average interest rate predicted by almost all models is considerably higher than the average EONIA rate.

The first two moments of a time-series provide only very rough measures of the goodness of fit. Therefore, we base our selection on three further criteria frequently employed in the literature: $:^{23}$ the root mean square error (RMSE), the mean absolute error (MAE) and the mean absolute percentage error (MAPE). In doing so, we always evaluate the difference between the actual EONIA and the predicted interest rate path. To make an informed judgment, we implement the statistic proposed by Diebold and Mariano (2002) that allows to test whether two competing forecasts differ in their prediction accuracy. In our case, we test whether the outcome of a particular decision model explains the path of the actual interest rate (EONIA) better than our best-performing model, i.e., the output gap model with a federalist board.

${ }^{23}$ See, e.g. Riboni and Ruge-Murcia (2010) and Hayo and Méon (2013). 
Table 2 presents our main results: We compare the goodness of fit of each decision model in predicting the actual interest rate (EONIA) during the period January 1999 to December 2006 based on our three selection criteria. Among the different specifications, the output gap model with a federalist board is the best-performing model regarding all three criteria. It yields a RMSE of 0.44 , a MAE of 0.37 and a MAPE of 0.13 . The version with a nationalist board performs slightly worse (RMSE of 0.55 , MAE of 0.42 and MAPE of 0.13 ), however, the null hypothesis that the forecast accuracy of the two models is equal cannot be rejected. The preferred rate model performs also quite well in explaining EONIA with a RMSE of 0.65 , a MAE of 0.67 and a MAPE of 0.26 in the case of a federalist board and with a RMSE of 0.73, a MAE of 0.56 and a MAPE of 0.22 in the case of a nationalist board. The Diebold Mariano test statistic indicates that the prediction of the preferred rate model is already statistically different from (and thus worse than) the prediction of the output gap model. However, both weak country models clearly improve on the bargaining model with simple GDP weights which yields a RMSE of 0.89 , a MAE of 0.85 and a MAPE of 0.32 in the federalist board version. Consistent with the findings of Hayo and Méon (2013) the simple bargaining, the median voting model and the consensus

Table 2

Explanatory power of the decision models in explaining EONIA

\begin{tabular}{llllc}
\hline Decision model & \multicolumn{1}{c}{ Preferences } & RMSE & MAE & MAPE \\
\hline Output gap & Federalist board & 0.44 & 0.37 & 0.13 \\
Output gap & Nationalist board & $0.55(0.12)$ & $0.42(0.55)$ & $0.13(0.99)$ \\
Preferred rate & Federalist board & $0.65(0.00)$ & $0.67(0.00)$ & $0.26(0.01)$ \\
Preferred rate & Nationalist board & $0.73(0.06)$ & $0.56(0.07)$ & $0.22(0.00)$ \\
Simple bargaining & Federalist board & $1.18(0.00)$ & $1.13(0.00)$ & $0.41(0.00)$ \\
Simple bargaining & Nationalist board & $1.33(0.00)$ & $1.28(0.00)$ & $0.47(0.00)$ \\
GDP bargaining & Federalist board & $0.89(0.00)$ & $0.85(0.00)$ & $0.32(0.00)$ \\
GDP bargaining & Nationalist board & $0.87(0.00)$ & $0.81(0.00)$ & $0.31(0.00)$ \\
Majority voting & Federalist board & $0.90(0.00)$ & $0.86(0.00)$ & $0.32(0.00)$ \\
Majority voting & Nationalist board & $1.21(0.00)$ & $1.13(0.00)$ & $0.41(0.00)$ \\
Consensus & Federalist board & $0.94(0.00)$ & $0.90(0.00)$ & $0.34(0.00)$ \\
Consensus & Nationalist board & $1.37(0.00)$ & $1.27(0.00)$ & $0.48(0.00)$ \\
Chairman Dominance & Federalist board & $1.33(0.02)$ & $1.11(0.00)$ & $0.38(0.00)$ \\
Chairman Dominance & Nationalist board & $1.66(0.01)$ & $1.40(0.00)$ & $0.46(0.00)$ \\
Franco-German dominance & & $0.60(0.09)$ & $0.52(0.13)$ & $0.20(0.11)$ \\
\hline
\end{tabular}

Note: The sample ranges from January 1999 to December 2006. The output gap model defines an unfor- tunate economic situation if a country's output gap is smaller or more negative than the euro area output gap. The preferred rate model refers to a country as weak if the nationally preferred interest rate is lower than the (GDP-weighted) euro area average. For the details of the further decision models see section IV. In the "federalist board" scenarios, the executive board is assumed to take a common euro area perspective. In the the "nationalist board" scenario, the executive board members represent their home countries' in- terests. Based on Diebold and Mariano (2002) we test the null hypothesis that the forecast accuracy equal and use the output gap model with a federalist board as benchmark. $\mathrm{P}$-values in parenthesis. 
model generally tend to perform worse in explaining the actual EONIA path than the GDP bargaining model. Only the majority voting and the consensus model with a federalist board yield results that come close to the performance of the GDP bargaining model.

In sum, our analysis suggests that the ECB's monetary policy favors countries that fare economically worse than the euro area average - even before the advent of the financial crisis. These countries obtain a higher weight in the bargaining process than implied by their economic size as measured by GDP. This suggests that the national representatives in the Governing Council are especially active when their home country faces a crisis. Bindseil (2001) contends that governors are politically not fully independent of their home country and Heinemann and Huefner (2004) argue that governors are influenced by being under the spotlight of their home countries' media. ${ }^{24}$ Political pressure from politics and media attention for monetary policy is more pronounced if a country faces an economically difficult period. Therefore, governors of these countries seem to exert a lot more effort than usually to influence the common monetary policy. At the same time, it is quite unlikely that governments of prospering countries put pressure on their central bank governors to increase interest rates to curb the potential negative consequences of a booming economy.

As regards the position of the executive board our analysis is not fully conclusive. In most specifications the performance of a model declines when changing the assumption from a federalist to a nationalist board. This suggests that the executive board members are more independent from their home countries' interests and care for the entire euro area. However, further tests (only shown in the case of the output gap model) reveal that the two specifications are indistinguishable in most cases.

The output gap and the preferred rate model define certain euro area member countries as weak which then obtain an additional weight in the decision process. For our main results displayed in Table 2, we simply assume that weak countries obtain the (normalized) double GDP weight which is, of course, just a very rough approximation. To get a better understanding of the actual additional weight, we conduct a sensitivity analysis. Table 3 shows the results of our analysis for the different weighting factors $1.5,2,3,5,10$ and 100. Under all three selection criteria the output gap model performs best (or at least as good) with the specification of a double weight. However, the Diebold Mariano test reveals that there is no statistically significant difference between the specifications with a weight of two and that with a weight of three when assuming a federalist board. This finding indicates that there is a considerable, but not too strong emphasis on

\footnotetext{
${ }^{24}$ For empirical evidence that governors are influenced by regional consideration in the US context see Havrilesky and Gildea (1995) and Meade and Sheets (2002). Ehrmann and Fratzscher (2011) distinguish pressure coming from low-growth and high-growth countries by analyzing measures for political pressure on the ECB.
} 
Table 3

Weak country decision models with different weights

\begin{tabular}{|c|c|c|c|c|c|c|}
\hline \multirow{2}{*}{$\frac{\text { Decision model }}{\text { Decision criterion }}$} & \multicolumn{3}{|c|}{ Output gap } & \multicolumn{3}{|c|}{ Preferred rate } \\
\hline & RMSE & MAE & MAPE & RMSE & MAE & MAPE \\
\hline \multicolumn{7}{|l|}{ weight $=1.5$} \\
\hline Federalist board & $0.56(0.00)$ & $0.49(0.01)$ & $0.19(0.03)$ & $0.79(0.00)$ & $0.74(0.00)$ & $0.28(0.00)$ \\
\hline Nationalist board & $0.81(0.00)$ & $0.74(0.00)$ & $0.28(0.00)$ & $0.73(0.01)$ & $0.65(0.01)$ & $0.25(0.02)$ \\
\hline \multicolumn{7}{|l|}{ weight $=2$} \\
\hline Federalist board & 0.44 & 0.37 & 0.13 & $0.65(0.00)$ & $0.67(0.00)$ & $0.26(0.01)$ \\
\hline Nationalist board & $0.55(0.12)$ & $0.42(0.55)$ & $0.13(0.99)$ & $0.73(0.06)$ & $0.56(0.07)$ & $0.22(0.00)$ \\
\hline \multicolumn{7}{|l|}{ weight $=3$} \\
\hline Federalist board & $0.53(0.17)$ & $0.41(0.63)$ & $0.13(0.91)$ & $0.66(0.01)$ & $0.59(0.01)$ & $0.230 .03)$ \\
\hline Nationalist board & $0.77(0.00)$ & $0.66(0.89)$ & $0.25(0.01)$ & $0.57(0.20)$ & $0.46(0.32)$ & $0.19(0.22)$ \\
\hline \multicolumn{7}{|l|}{ weight $=5$} \\
\hline Federalist board & $0.83(0.01)$ & $0.69(0.02)$ & $0.23(0.03)$ & $0.60(0.08)$ & $0.51(0.09)$ & $0.20(0.10)$ \\
\hline Nationalist board & $0.79(0.01)$ & $0.66(0.00)$ & $0.24(0.00)$ & $0.51(0.42)$ & $0.42(0.57)$ & $0.16(0.37)$ \\
\hline \multicolumn{7}{|l|}{ weight $=10$} \\
\hline Federalist board & $1.19(0.00)$ & $1.08(0.00)$ & $0.36(0.00)$ & $0.55(0.22)$ & $0.45(0.30)$ & $0.18(0.22)$ \\
\hline Nationalist board & $0.84(0.02)$ & $0.68(0.00)$ & $0.24(0.00)$ & $0.48(0.56)$ & $0.39(0.73)$ & $0.15(0.51)$ \\
\hline \multicolumn{7}{|l|}{ weight $=100$} \\
\hline Federalist board & $1.74(0.00)$ & $1.63(0.00)$ & $0.54(0.00)$ & $0.50(0.45)$ & $0.41(0.59)$ & $0.16(0.39)$ \\
\hline Nationalist board & $0.96(0.07)$ & $0.73(0.00)$ & $0.26(0.00)$ & $0.48(0.49)$ & $0.39(0.70)$ & $0.15(0.53)$ \\
\hline
\end{tabular}

Note: The sample ranges from January 1999 to December 2006. The output gap model defines an unfortunate economic situation if a country's output gap is smaller or more negative than the euro area output gap. The preferred rate model refers to a country as weak if the nationally preferred interest rate is lower than the (GDP-weighted) euro area average. For the details of the further decision models see section IV. In the "federalist board" scenarios, the executive board is assumed to take a common euro area perspective. In the the "nationalist board" scenario, the executive board members represent their home countries' interests. Based on Diebold and Mariano (2002) we test the null hypothesis that the forecast accuracy equal and use the output gap model with a federalist board as benchmark. P-values in parenthesis.

the output gap in the ECB's decision process. The performance of the preferred rate model improves as countries with a lower-than-average preferred interest rate become more important. Interestingly, the performance of the preferred rate model almost converges to that of the best-performing output gap model as the weighting factor increases. Moreover, the Diebold Mariano test indicates that the preferred rate model is no more statistically different from our bestperforming model as soon as the weighting factor reaches three in case of a nationalist board or 10 in case of a federalist the board. These results indicate that (as expected) the governors are not exclusively concerned with the deviation of their country's output from its trend, but with inflation as well. Since the output gap model ignores inflation issues, it becomes an unrealistic description of actual ECB policy if too much weight is put on the output gap. The preferred rate model, however, can explain actual ECB policy if the very strong emphasis on the weak countries is considered plausible. 
A deeper question is whether our weak country decision models actually capture countries that face economic difficulties in general or whether they capture the dominant influence of France and Germany. Both countries faced a difficult economic situation throughout most of our sample period which might confound our findings. To disentangle the forces that drive our results, we plot the preferred interest rates for France and Germany together (weighted with their respective GDP) and compare this "Franco-German-dominance" model to EONIA. When looking at the graphical illustration (see Figure $1(\mathrm{~h})$ ) it becomes evident that the Franco-German dominance model is a good approximation only from around 2000 to 2002, thereafter its prediction is less accurate. In total, the output gap model outperforms the Franco-German dominance model with respect to all three selection criteria (see Table 2). This result suggests that the ECB's behavior is best explained by a bias towards economically weak countries instead of bias towards France and Germany.

\section{ROBUSTNESS}

There are many ways to estimate counterfactual interest rates in a Taylor rule framework, the resulting coefficients depend considerably on the specification of the calibration, but there is no clear consensus which is the best procedure.

\section{Table 4}

Model fit with Taylor rule estimates based on Taylor (1993)

\begin{tabular}{lllll}
\hline Decision model & \multicolumn{1}{c}{ Preferences } & RMSE & MAE & MAPE \\
\hline Output gap & Federalist board & 0.71 & 0.62 & 0.24 \\
Output gap & Nationalist board & $1.18(0.00)$ & $1.06(0.00)$ & $0.40(0.00)$ \\
Preferred rate & Federalist board & $1.19(0.00)$ & $1.08(0.00)$ & $0.41(0.00)$ \\
Preferred rate & Nationalist board & $1.11(0.00)$ & $0.97(0.00)$ & $0.38(0.00)$ \\
Simple bargaining & Federalist board & $1.18(0.00)$ & $1.24(0.00)$ & $0.47(0.00)$ \\
Simple bargaining & Nationalist board & $1.33(0.00)$ & $1.49(0.00)$ & $0.55(0.00)$ \\
GDP bargaining & Federalist board & $1.55(0.00)$ & $1.46(0.00)$ & $0.54(0.00)$ \\
GDP bargaining & Nationalist board & $1.30(0.00)$ & $1.20(0.00)$ & $0.46(0.00)$ \\
Majority voting & Federalist board & $1.66(0.00)$ & $1.53(0.00)$ & $0.58(0.00)$ \\
Majority voting & Nationalist board & $1.23(0.00)$ & $1.14(0.00)$ & $0.43(0.00)$ \\
Consensus & Federalist board & $1.96(0.00)$ & $1.79(0.00)$ & $0.64(0.00)$ \\
Consensus & Nationalist board & $1.30(0.00)$ & $1.21(0.00)$ & $0.46(0.00)$ \\
Chairman Dominance & Federalist board & $1.25(0.00)$ & $1.14(0.00)$ & $0.44(0.00)$ \\
Chairman Dominance & Nationalist board & $1.86(0.02)$ & $1.64(0.00)$ & $0.59(0.00)$ \\
\hline
\end{tabular}

Note: The sample ranges from January 1999 to December 2006. The output gap model defines an unfortunate economic situation if a country's output gap is smaller or more negative than the euro area output gap. The preferred rate model refers to a country as weak if the nationally preferred interest rate is lower than the (GDP-weighted) euro area average. For the details of the further decision models see section IV. In the "federalist board" scenarios, the executive board is assumed to take a common euro area perspective. In the the "nationalist board" scenario, the executive board members represent their home countries' interests. Based on Diebold and Mariano (2002) we test the null hypothesis that the forecast accuracy equal and use the output gap model with a federalist board as benchmark. P-values in parenthesis. 
Therefore, we use the average of three different estimates as employed by Hayo and Méon (2013) in our main specification. In the following, we present variations of our results based on the specifications by Eleftheriou, Gerdesmeier, and Roffia (2006), Hayo (2007) and Taylor (1993) separately.

Table 4 shows the outcome of our analysis when employing counterfactual interest paths that are based on Taylor's original coefficients. The specification entails the clear advantage of being independent, but is at the same time only a very rough estimate and certainly more adequate for the US context. Nevertheless, the corresponding results con- firm our baseline finding as the output gap model with a federalist board approximates actual interest rates best. Interestingly, the simple bargaining model also performs quite well and even outperforms the GDP bargaining model.

Eleftheriou, Gerdesmeier, and Roffia (2006) estimate Taylor-type interest rate rules with monthly national data for eleven EMU countries in the period from 1993 to 1998. They find that the rules followed by the individual countries are distinct and differ substantially from the standard Taylor rule. Table 5 presents the results when using counterfactual interest paths based on these coefficients: again, the output gap model with a federalist board performs best, whereas the relative performance of the other models changes bit a: the consensus and

\section{Table 5}

Model fit with Taylor rule estimates based on Eleftheriou (2006)

\begin{tabular}{lllll}
\hline Decision model & \multicolumn{1}{c}{ Preferences } & RMSE & MAE & MAPE \\
\hline Output gap & Federalist board & 0.44 & 0.32 & 0.11 \\
Output gap & Nationalist board & $0.64(0.00)$ & $0.58(0.00)$ & $0.21(0.00)$ \\
Preferred rate & Federalist board & $0.55(0.03)$ & $0.56(0.01)$ & $0.22(0.02)$ \\
Preferred rate & Nationalist board & $0.63(0.16)$ & $0.47(0.06)$ & $0.18(0.05)$ \\
Simple bargaining & Federalist board & $0.84(0.02)$ & $0.76(0.01)$ & $0.30(0.01)$ \\
Simple bargaining & Nationalist board & $0.98(0.01)$ & $0.90(0.01)$ & $0.35(0.01)$ \\
GDP bargaining & Federalist board & $0.73(0.01)$ & $0.68(0.00)$ & $0.26(0.00)$ \\
GDP bargaining & Nationalist board & $0.74(0.01)$ & $0.68(0.00)$ & $0.26(0.01)$ \\
Majority voting & Federalist board & $0.68(0.02)$ & $0.62(0.00)$ & $0.24(0.01)$ \\
Majority voting & Nationalist board & $0.85(0.04)$ & $0.74(0.02)$ & $0.30(0.02)$ \\
Consensus & Federalist board & $0.55(0.05)$ & $0.66(0.01)$ & $0.26(0.02)$ \\
Consensus & Nationalist board & $1.00(0.06)$ & $0.83(0.06)$ & $0.32(0.05)$ \\
Chairman Dominance & Federalist board & $1.24(0.10)$ & $0.99(0.04)$ & $0.35(0.02)$ \\
Chairman Dominance & Nationalist board & $1.29(0.08)$ & $1.03(0.03)$ & $0.37(0.01)$ \\
\hline
\end{tabular}

Note: The sample ranges from January 1999 to December 2006. The output gap model defines an unfortunate economic situation if a country's output gap is smaller or more negative than the euro area output gap. The preferred rate model refers to a country as weak if the nationally preferred interest rate is lower than the (GDP-weighted) euro area average. For the details of the further decision models see section IV. In the "federalist board" scenarios, the executive board is assumed to take a common euro area perspective. In the the "nationalist board" scenario, the executive board members represent their home countries' interests. Based on Diebold and Mariano (2002) we test the null hypothesis that the forecast accuracy equal and use the output gap model with a federalist board as benchmark. P-values in parenthesis. 
Table 6

Model fit with Taylor rule estimates based on Hayo (2007)

\begin{tabular}{lllll}
\hline Decision model & \multicolumn{1}{c}{ Preferences } & RMSE & MAE & MAPE \\
\hline Output gap & Federalist board & 0.69 & 0.53 & 0.18 \\
Output gap & Nationalist board & $0.88(0.09)$ & $0.68(0.10)$ & $0.24(0.07)$ \\
Preferred rate & Federalist board & $0.70(0.83)$ & $0.52(0.92)$ & $0.18(0.90)$ \\
Preferred rate & Nationalist board & $0.68(0.97)$ & $0.55(0.69)$ & $0.19(0.64)$ \\
Simple bargaining & Federalist board & $1.45(0.06)$ & $1.15(0.01)$ & $0.39(0.00)$ \\
Simple bargaining & Nationalist board & $1.61(0.07)$ & $1.26(0.01)$ & $0.42(0.01)$ \\
GDP bargaining & Federalist board & $0.85(0.26)$ & $0.63(0.49)$ & $0.22(0.37)$ \\
GDP bargaining & Nationalist board & $0.81(0.25)$ & $0.61(0.51)$ & $0.22(0.40)$ \\
Majority voting & Federalist board & $0.88(0.25)$ & $0.64(0.44)$ & $0.23(0.34)$ \\
Majority voting & Nationalist board & $1.24(0.09)$ & $0.97(0.03)$ & $0.35(0.02)$ \\
Consensus & Federalist board & $0.93(0.19)$ & $0.70(0.30)$ & $0.25(0.23)$ \\
Consensus & Nationalist board & $1.18(0.02)$ & $1.02(0.00)$ & $0.36(0.00)$ \\
Chairman Dominance & Federalist board & $1.73(0.02)$ & $1.40(0.00)$ & $0.46(0.00)$ \\
Chairman Dominance & Nationalist board & $1.87(0.00)$ & $1.53(0.00)$ & $0.53(0.00)$ \\
\hline
\end{tabular}

Note: The sample ranges from January 1999 to December 2006. The output gap model defines an unfortunate economic situation if a country's output gap is smaller or more negative than the euro area output gap. The preferred rate model refers to a country as weak if the nationally preferred interest rate is lower than the (GDP-weighted) euro area average. For the details of the further decision models see section IV. In the "federalist board" scenarios, the executive board is assumed to take a common euro area perspective. In the the "nationalist board" scenario, the executive board members represent their home countries' interests. Based on Diebold and Mariano (2002) we test the null hypothesis that the forecast accuracy equal and use the output gap model with a federalist board as benchmark. P-values in parenthesis.

majority voting models now outperform the bargaining models and catch up with the preferred rate model.

Hayo (2007) estimates long-run monetary policy reaction functions that are based on the last 20 years before the introduction of the Euro. These rules relate interest rate setting to the expected one-year ahead inflation rate and the current output gap. Table 6 presents our results based on the corresponding counterfactual interest paths. As before the output gap model with a federalist board is among the best approximations of the ECB's actual interest rate policies. Interestingly, the performance of the preferred rate model with a federalist board is as good as our benchmark. When assuming a nationalist board, the preferred rate model even outperforms the output gap model. In general, the distinctions between the different models become more blurred when only using the time-series estimated by Hayo (2007). For example, the fit of the GDP bargaining, the majority voting and the consensus model is no longer statistically different from our benchmark.

\section{CONCLUSION}

In this paper, we elaborate on the decision mechanism of the ECB's Governing Council. To that end, we approximate the interest rates desired by the individual euro area member countries by counterfactual national interest rate paths for 
the period 1999-2006. These paths are aggregated following various potential decision models for the ECB's Governing Council. We focus on models that emphasize the weight of countries which face unfortunate economic conditions. We show that these refinements of the bargaining model perform better than simple bargaining models which were regarded as best explanation in the previous literature. We explain our findings by behavioral responses of central bank governors to political and media pressure as documented by Bindseil (2001) and Heinemann and Huefner (2004): National governors confront more political pressure if their home country faces a recession and hence exert more effort to influence the common monetary policy. Of course, there exist alternative explanations. For example, the ECB might intend to support crisis countries as they have lost monetary policy and devaluation as options for economic improvement. This question certainly deserves further research although it is not trivial to think of scenarios that allow to disentangle the different explanations neatly as long as information on the individual voting behavior of central bank governors is not publicly available.

Our results are particularly relevant since the distribution of power between central and regional interests is crucial for the efficiency of monetary policies (see, e.g., von Hagen and Süppel (1994)). A monetary policy in a currency union that puts special weight on countries that fare economically worse than the average can contribute to a convergence of the euro area member states. ${ }^{25}$ However such a policy comes at considerable risks: if the ECB was willing to trade-off price stability in booming countries with accommodating the economic needs of distressed countries, price level instabilities in economic stronger countries can arise, with potential detrimental consequences for the real economies and welfare (see, for example, Woodford (2002)). Such a monetary policy, if done systematically, can in the longer run entail an inflationary bias. However, it should be emphasized that in the euro area such an inflation bias has not been observed up to date. One reason could be, that economic situations changed frequently in the early years of the euro area, such that no country was systematically neglected or favored over a long time horizon. ${ }^{26}$

\section{REFERENCES}

Aksoy, Y., P. de Grauwe, and H. Dewachter (2002): "Do Asymmetries Matter for European Monetary Policy?," European Economic Review, 46, 443-469.

Alesina, A., and V. Grilli (1992): "The European Central Bank: Reshaping Monetary Politics in Europe," in Establishing a Central Bank: Issues in Europe and Lessons from the US, ed. by A. Alesina, V. Grilli and M. Canzoneri. Cambridge Univerity Press, Cambridge.

\footnotetext{
${ }^{25}$ Aksoy, de Grauwe, and Dewachter (2002) show that welfare is in general improved if the Governing Council takes a euro-wide perspective compared with nationalistic regime where all governors act in the interest of their country.

${ }^{26}$ For a discussion on the macroeconomic performance of euro area member countries post euro introduction see, e.g., Lane (2006).
} 
Bénassy-Quéré, A., and E. Turkish (2009): "The ECB Governing Council in an Enlarged Euro Area," Journal of Common Market Studies, 47(1), 25-53.

Bennani, H., and M. Neuenkirch (2017): "The (home) bias of European central bankers: new evidence based on speeches," Applied Economics, 49(11), 1114-1131.

Berger, H., and J. de Haan (2002): "Are Small Countries Too Powerful Within the ECB?," Atlantic Economic Journal, 30, 1-20.

Bindseil, U. (2001): "A Coalition-Form Analysis of the'One-Country-One-Vote' Rule in the Governing Council of the European Central Bank," International Economic Journal, 15(1), $141-164$.

Borio, C. E. V. (1997): "The Implementation of Monetary Policy in Industrial Countries: A Sur- vey," BIS Economic Papers, (47).

Diebold, F. X., and R. S. Mariano (2002): “Comparing Predictive Accuracy," Journal of Business \& Economic Statistics, 20(1), 134-144.

Duisenberg, W. (2002): "Some remarks on the euro in a US context," Speech at a breakfast meeting of the Council of Foreign Relations, New York, 19 April (www.ecb.int.).

Ehrmann, M., and M. Fratzscher (2011): "Politics and monetary policy," Review of Economics and Statistics, 93(3), 941-960.

Eleftheriou, M., D. Gerdesmeier, and B. Roffia (2006): "Monetary policy rules in the pre-EMU era: Is there a common rule?," European Central Bank Working Paper, (0659).

Farvaque, E., P. Stanek, and S. Vigeant (2014): "On the performance of monetary policy committees," Kyklos, 67(2), 177-203.

Gildea, J. A. (1992): "The regional representation of Federal Reserve Bank presidents," Journal of Money, Credit and Banking, 24(2), 215-225.

Gros, D., and C. Hefeker (2002): "One Size Must Fit All: National Divergence in a Monetary Union," German Economic Review, 3, 247-262.

Gunzinger, F., and J.-E. Sturm (2016): "It's Politics, Stupid! Political Constraints Determined Governments' Reactions to the Great Recession," Kyklos, 69(4), 584-603.

Havrilesky, T., and J. Gildea (1995): "The Biases of Federal Reserve Bank Presidents," Economic Inquiry, 33(1), 274-284.

Hayo, B. (2007): "Is European Monetary Policy Appropriate for the EMU Member Countries? A Counterfactual Analysis," in The Travails of the Eurozone, ed. by D. Cobham. Houndmills: Palgrave MacMillan.

Hayo, B., and P.-G. Méon (2013): "Behind closed doors: Revealing the ECB's decision rule," Journal of International Money and Finance, 37, 135-160.

Heinemann, F., and F. P. Huefner (2004): "Is the View from the Eurotower Purely European?- National Divergence and ECB Interest Rate Policy," Scottish Journal of Political Economy, 51, 544-558.

Jung, A., and S. Latsos (2015): "Do federal reserve bank presidents have a regional bias?," Euro- pean Journal of Political Economy, 40, 173-183.

Lane, Philip R (2006): "The real effects of European monetary union," Journal of Economic Perspectives, 20, 47-66.

Meade, E. E., and D. Sheets (2002): "Regional Influences on Regional Monetary Policy: Some Implivations for Europe," Board of Governors of the Federal Reserve System, International Finance Discussion Paper, (271).

Meade, E. E., and D. N. Sheets (2005): "Regional influences on FOMC voting patterns," Journal of Money, Credit, and Banking, 37(4), 661-677.

Riboni, A., and F. J. Ruge-Murcia (2010): "Monetary Policy by Committee: Consensus, Chairman Dominance, or Simple Majority," Quarterly Journal of Economics, 125, 363-416.

Sturm, J., and T. Wollmershäuser (2008): "The Stress of Having a Single Monetary Policy in Europe," CESifo Working Paper, (2251). 


\section{MARCUS DROMETER/THOMAS SIEMSEN/SEBASTIAN WATZKA}

Taylor, J. (1993): "Discretion versus policy rules in practise," Carnegie-Rochester Conference on Public Policy, 39, 195-214.

The Economist (2016): "Mario battles the Wutsparer," 30.04.2016.

Tillmann, P. (2011): "Strategic forecasting on the FOMC," European Journal of Political Economy, 27(3), 547-553.

Ullrich, K. (2006): "The Impact of Country-Specific Economic Developments on ECB Decisions," ZEW Discussion Paper, (06-049).

von Hagen, J., and R. Süppel (1994): "Central Bank Constitutions for Federal Monetary Unions," European Economic Review, 38(3-4), 774-782.

Wirtschaftswoche (2013): "Die Eurokrise ist noch nicht vorbei: Interview mit Jens Weidmann," 30.04.2013.

Woodford, M. (2002): "Inflation stabilization and welfare," Contributions in Macroeconomics, 2(1).

\section{SUMMARY}

This paper investigates the extent to which national economic conditions matter in the ECB's decision process. We employ various decision models to aggregate counterfactual national interest rates based on Taylor rule estimates and test which of the resulting interest paths fits best to the actual monetary policy in the euro area. As a novel feature, we introduce decision models where countries that fare economically worse than the euro area average obtain a higher weight in the decision process. Our results suggest that these models explain actual ECB policy better than GDP-based bargaining models that have been highlighted in the previous literature. Thus, the ECB seems to have emphasized the needs of countries that face an economic crisis disproportionately highly even before the advent of the financial crisis. 